\title{
Synchronous Estimation of Glycopyrrolate and Formoterol in Bulk and Pharmaceutical Dosage Form by RP-HPLC Method
}

\author{
Kishor Kumar Erukulla, Suseem Sundaram Rengitham* \\ Department of Chemistry, VIT University, Vellore, Tamilnadu, INDIA.
}

\begin{abstract}
Objective: The objective is to develop and validate a fundamental, specific, novel and exact RP-HPLC (Reverse phase-High performance Liquid chromatography) methodology for the synchronous determination of Glycopyrrolate and Formoterol in pharmaceutical dosage form. Methods and Materials: The column utilized was BDS $C_{18}(250 \mathrm{~mm} x$ $4.6 \mathrm{~mm}, 5 \mu \mathrm{m})$ in isocratic mode, with mobile phase consist of phosphate buffer and acetonitrile (40:60 v/v). The buffer was made by adding $1 \mathrm{ml}$ of Orthophosphoric acid in a $1000 \mathrm{ml}$ of volumetric flask and about $900 \mathrm{ml}$ of milli- $\mathrm{Q}$ water, degas to sonicate and lastly make up the quantity with water. The flow rate used was $1.0 \mathrm{ml} / \mathrm{min}$ and effluents were monitored at $241 \mathrm{~nm}$. Results: The retention times of Glycopyrrolate and Formoterol are $2.290 \mathrm{~min}$ and $2.853 \mathrm{~min}$, respectively. The linearity for Glycopyrrolate and Formoterol are $2.25-13.5 \mu \mathrm{g} / \mathrm{ml}$ and $1.2-7.2 \mu \mathrm{g} / \mathrm{ml}$ respectively. The recoveries of Glycopyrrolate and Formoterol were observed to be 99.17 to $100.66 \%$ and 98.36 to $100.79 \%$ respectively. Conclusion: The validation was performed for the proposed method and applied successfully for the determination of Glycopyrrolate and Formoterol. The method was found to be precise, accurate for the synchronous determination of Glycopyrrolate and Formoterol in pharmaceutical dosage form.
\end{abstract}

Key words: Glycopyrrolate, Formoterol, Validation, HPLC.

\section{INTRODUCTION}

Glycopyrrolateis aquaternaryammoniumsalt. Chemically, Glycopyrrolate is (RS)-[3(SR)Hydroxy-1, 1-dimethylpyrrolidinium bromide] $\alpha$-cyclopentylmandelate. The chemical formula is $\mathrm{C}_{19} \mathrm{H}_{28} \mathrm{BrNO}_{3}$. The molecular weight is $398.33 \mathrm{~g} / \mathrm{mol} .{ }^{1}$ Glycopyrrolate is a crystalline white powder. It is dissolvable in water and alcohol, and much insoluble in chloroform and ether. ${ }^{2}$

Glycopyrrolate, as other anticholinergic (antimuscarinic) drugs, impedes the action of acetylcholine on structures innervated by postganglionic cholinergic nerves and on smooth muscles that respond to acetylcholine yet require cholinergic innervation. Thus, it diminishes the volume and free acidity of gastric secretions and controls excessive pharyngeal, tracheal, and bronchial secretions. ${ }^{3}$

Formoterol acts as a bronchodilator. It extends the airways of the lungs, so that it helps to inhale all the more effortlessly. It may even be utilized to forestall respiratory issues caused by exercise. It can also be utilized for long-term treatment of chronic obstructive pulmonary disease (COPD). ${ }^{4}$ Chemically, Formoterol is N-[2-Hydroxy5-[(1RS)-1-hydroxy-2-[[(1RS)-2(4-methoxyphenyl) -1-methylethyl]-amino] ethyl] phenyl] formamide (E)-2-butenedioate dihydrate. The chemical formula is $\mathrm{C}_{19} \mathrm{H}_{24} \mathrm{~N}_{2} \mathrm{O}_{4}$. $\mathrm{C}_{4} \mathrm{H}_{4} \mathrm{O}_{4} \cdot 2 \mathrm{H}_{2} \mathrm{O}$. The molecular weight is $840.91 \mathrm{~g} / \mathrm{mol}^{1}$

There are various analytical methods reported in the literature for the assay of
Submission Date: 18-09-2017 Revision Date: 08-11-2017; Accepted Date: 18-04-2018

DOI: 10.5530/ijper.52.4s.75 Correspondence: Dr. Suseem Sundaram Rengitham, Department of Chemistry, VIT University, Vellore, Tamilnadu-632014, INDIA. Phone: 04162202331

E-mail: srsuseem@vit.ac.in

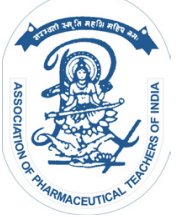

www.ijper.org 
Glycopyrrolate and Formoterol separately and also with other drugs include spectrophotometry, HPLC, HPTLC and other types.

For only Glycopyrrolate separate RP HPLC methods were available in bulk, tablet dosage forms, ${ }^{5}$ and for parenterals. ${ }^{3}$ There is also a method for glycopyrrolate alone in human plasma by liquid chromatographyelectrospray ionization mass spectrometry ${ }^{6}$ and liquid chromatography-Tandem mass spectrometry method for quantification of Glycopyrrolate in horse plasma. ${ }^{7}$

There are various methods for determination for single formoterol alone, like Automated and sensitive method for the determination of formoterol in human plasma by high-performance liquid chromatography and electrochemical detection. ${ }^{8}$ There are various RP-HPLC methods for the Simultaneous estimation of Formoterol Fumarate and Tiotropium Bromide, ${ }^{9}$ Formoterol Fumarate and Budesonide in metered dose inhaler formulation, ${ }^{10}$ spectroscopic method for the simultaneous estimation of Mometasone Furoate and Formoterol Fumarate in Rotacaps. ${ }^{11}$ chromatographic methods for the simultaneous determination of Mometasone furoate and Formoterol fumarate dihydrate in a combined dosage form ${ }^{12}$ and for Estimation of Formoterol Fumarate and Mometasone Furoate in Metered Dose Inhalation Form by High Performance Liquid Chromatography, ${ }^{13}$ UV spectroscopie method for the determination of beclomethasone dipropionate and formoterol fumarate in rotacap dosage form, ${ }^{4}$ Simultaneous spectroscopic determination of formoterol fumarate and budesonide in their combined dosage form, ${ }^{14}$ RP-HPLC method for estimation of formoterol fumarate and budesonide in pressurised meter dose inhaler form, ${ }^{15}$ Simultaneous ReversedPhase HPLC Method for Formoterol Fumarate and Fluticasone Propionate in Metered dose inhaler. ${ }^{16}$

As per the literature survey no reported method was available for the simultaneous determination of Glycopyrrrolate and Formoterol. The present method was to build up a straightforward, minimal effort RP-HPLC technique for concurrent estimation of Glycopyrrolate and Formoterol in bulk and also in other dosage forms. The method was validated according to ICH guidelines. ${ }^{17}$

\section{MATERIALS AND METHODS}

\section{Reagents}

Glycopyrrolate and Formoterol were supplied by Astra Zeneca. Acetonitrile, water (HPLC review, Merck) and the various reagents were acquired from $M R$ Enterprisers. The tablets BEVESPI AEROSPHERE (AstraZeneca) containing $8 \mathrm{mg}$ of Glycopyrrolate and $25 \mathrm{mg}$ of Formoterol were used.

\section{Instrumentation}

The LC system comprised of a Waters model 515, PDA detector 2998 with twenty $\mu \mathrm{L}$ sample loop. The output signals were observed and integrated utilizing Empower 2 software.

\section{Chromatographic conditions}

The elution method was isocratic. The mobile phase is comprised of a mixture of buffer ( $1 \mathrm{ml}$ of Orthophosphoric acid kept in a $1000 \mathrm{ml}$ of volumetric flask, around $900 \mathrm{ml}$ of milli-Q water was added, degas to sonicate lastly make up the volume with water) and acetonitrile $(40: 60 \mathrm{v} / \mathrm{v})$. The mobile phase was filtered through a $0.45-\mu \mathrm{m}$ (HVLP, Germany) membrane filter before using the same. A BDS $C_{18}(250 \mathrm{~mm} \times 4.6 \mathrm{~mm}, 5 \mathrm{~mm})$ column was utilized for determination. The rate of flow was $1.0 \mathrm{ml} / \mathrm{min}$ and also the column was operated at temperature $\sim 30^{\circ} \mathrm{C}$. The sample volume injected was $10 \mu \mathrm{L}$. The column was equilibrated for not less than $30 \mathrm{~min}$ with mobile phase flowing through the system prior to injection of the solutions. The wavelength of the UV detector was set at $241 \mathrm{~nm}$. A typical RP-HPLC chromatogram of Glycopyrrolate and Formoterol is presented in Figure 1.

\section{Diluent}

Water and ACN (50:50).

\section{Standard Preparation}

The weighing was done accurately and transferred $9 \mathrm{mg}$ of Glycopyrrolate and $4.8 \mathrm{mg}$ of Formoterol working Standards into a $100 \mathrm{ml}$ of volumetric flask, added $70 \mathrm{ml}$ of diluent, sonicated for $30 \mathrm{~min}$ and make up to the final volume with diluent. From the above stock solution, $1 \mathrm{ml}$ was taken out in to a $10 \mathrm{ml}$ volumetric flask and then make up to the final volume with diluents, to get a concentration of $9 \mathrm{mg} / \mathrm{ml}$ of Glycopyrrolate and $4.8 \mathrm{mg} / \mathrm{ml}$ of Formoterol.

\section{Sample Preparation}

Around 20 tablets were weighed accurately and crushed to a fine Powder and drug equivalent to $9 \mathrm{mg}$ and $4.8 \mathrm{mg}$ were kept in a $100 \mathrm{ml}$ volumetric flask, dissolved in diluent.

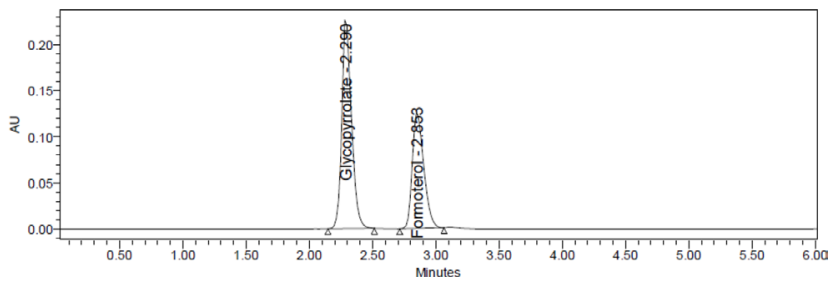

Figure 1: HPLC chromatogram of Glycopyrrolate and Formoterol. 
Then $1 \mathrm{ml}$ of the above solution was kept into a $10 \mathrm{ml}$ volumetric flask and filtered through $0.45 \mu$ membrane filter to get concentration of $9 \mu \mathrm{g} / \mathrm{ml}$ and $4.8 \mu \mathrm{g} / \mathrm{ml}$ for Glycopyrrolate and Formoterol.

\section{METHOD VALIDATION}

The developed method was validated as per ICH guidelines ${ }^{17}$ for its linearity, accuracy, precision, robustness, and specificity, limit of detection and limit of quantification by using the below mentioned procedures. The validated parameters are provided in Table 1.

\section{System suitability}

The validation of system suitability and chromatographic parameters was performed such as tailing factor, asymmetry factor, and number of theoretical plates were calculated.

\section{Linearity}

The linearity of this methodology was assessed by linear regression analysis and computed by least square method and studied by preparing standard solutions of Glycopyrrolate and Formoterol at various levels of concentrations. Peak area of the ensuing solutions was determined and additionally the calibration curve was plotted between Peak area versus concentration of the drug in Figure 2 and Figure 3. The response was observed to be linear in the range $2.25-13.5 \mu \mathrm{g} / \mathrm{ml}$ and $1.2-7.2 \mu \mathrm{g} / \mathrm{ml}$ for Glycopyrrolate and Formoterol. The information was provided in Table 2.1.

\section{Accuracy}

Accuracy was demonstrated in triplicate for numerous concentrations of Glycopyrrolate and Formoterol equivalent to $50 \%, 100 \%$ and $150 \%$ of the standard quantity were injected into the HPLC system per the test strategy. The typical recovery (\%) was computed. The data was given in Table 2.2.

\section{Precision}

\section{Precision Repeatability \\ System precision}

Six standard solutions of the similar concentration $(100 \%)$ were arranged and injected into the HPLC system as per test methodology. The outcomes were given in Table 3.1 (A).

\section{Method precision}

Six sample solutions of the identical concentration $(100 \%)$ were arranged and injected into the HPLC system as per test strategy. The results were given in Table 3.1(B).

\section{Intermediate Precision}

\section{Day to Day variability}

The study was conducted for two days according to test strategy. The six sample solutions of the identical concentration $(100 \%)$ were prepared and injected into the HPLC system as per test methodology for Day-1 and Day-2. The results were given in Table 3.2(A).

\section{Instrument to Instrument variability}

Two instruments were utilized according to the test method for the study. For Instrument-1 and Instrument-2, six sample solutions of the similar concentration (100\%) were arranegd and injected into the HPLC system as per test technique. The results were given in Table 3.2(B).

\begin{tabular}{|c|c|c|}
\hline \multirow{2}{*}{ Validation parameter (Units) } & \multicolumn{2}{|c|}{ Results } \\
\hline & Glycopyrrolate & Formoterol \\
\hline Linearity range $(\mu \mathrm{g} / \mathrm{ml})$ & $2.25-13.5$ & $1.2-7.2$ \\
\hline Regression equation & $y=13136 x+1558.6$ & $y=16066 x+666.5$ \\
\hline Correlation Coefficient( $r$ ) & 0.999 & 0.999 \\
\hline System Precision (\%RSD) & NMT 0.32 & NMT 0.43 \\
\hline Method Precision (\%RSD) & NMT 1.03 & NMT 0.28 \\
\hline $\begin{array}{l}\text { Intermediate Precision } \\
\text { (day-day) (\%RSD) }\end{array}$ & NMT 0.25 & NMT 0.26 \\
\hline Accuracy & $98.36 \%$ to $100.66 \%$ & $98.36 \%$ to $100.79 \%$ \\
\hline \multicolumn{3}{|c|}{ Robustness (\%RSD) } \\
\hline $\begin{array}{c}\text { Flow rate: } \\
(0.9 \mathrm{ml} / \mathrm{min} \text { and } 1.1 \mathrm{ml} / \mathrm{min})\end{array}$ & NMT 0.28 & NMT 1.12 \\
\hline $\begin{array}{c}\text { Mobile phase: } \\
\text { Buffer : ACN(40:60) }\end{array}$ & NMT 0.58 & NMT 0.98 \\
\hline Assay & $99.46 \pm 0.61$ & $98.74 \pm 0.36$ \\
\hline
\end{tabular}

RSD-Relative standard deviation, NMT-Not more than. ACN-Acetonitrile 

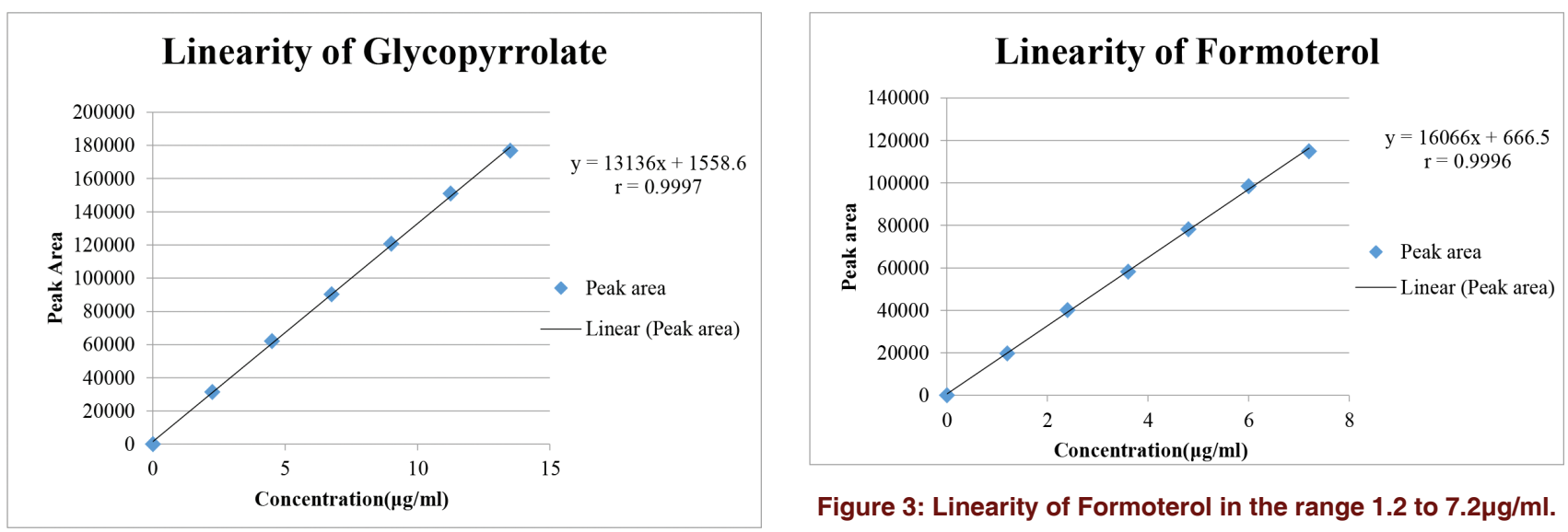

Figure 2: Linearity of Glycopyrrolate in the range 2.25 to $13.5 \mu \mathrm{g} / \mathrm{ml}$.

Figure 3: Linearity of Formoterol in the range 1.2 to $7.2 \mu \mathrm{g} / \mathrm{ml}$.

Table 2.1: Linearity Data of Glycopyrrolate and Formoterol.

\begin{tabular}{|c|c|c|c|c|c|c|}
\hline \multirow{2}{*}{ S.No } & \multicolumn{3}{|c|}{ Glycopyrrolate } & \multicolumn{3}{|c|}{ Formoterol } \\
\hline & Conc $(\mu \mathrm{g} / \mathrm{ml})$ & Rt(min) & Area & Conc $(\mu \mathrm{g} / \mathrm{ml})$ & $\operatorname{Rt}(\min )$ & Area \\
\hline 1 & 2.25 & 2.289 & 31371 & 1.2 & 2.85 & 19798 \\
\hline 2 & 4.5 & 2.287 & 61955 & 2.4 & 2.85 & 40114 \\
\hline 3 & 6.75 & 2.288 & 90106 & 3.6 & 2.851 & 58195 \\
\hline 4 & 9 & 2.286 & 120649 & 4.8 & 2.846 & 78179 \\
\hline 5 & 11.25 & 2.287 & 150911 & 6 & 2.847 & 98380 \\
\hline \multirow[t]{2}{*}{6} & 13.5 & 2.284 & 176601 & 7.2 & 2.847 & 114863 \\
\hline & \multicolumn{3}{|c|}{$\begin{array}{c}r=0.9997 \\
y=13136 x+1558.9\end{array}$} & \multicolumn{3}{|c|}{$\begin{array}{c}r=0.9996 \\
y=16066 x+666.5\end{array}$} \\
\hline
\end{tabular}

Rt-Retention time.

\begin{tabular}{|c|c|c|c|c|c|c|c|}
\hline \multirow[b]{2}{*}{ S.No } & \multirow[b]{2}{*}{$\begin{array}{c}\text { Spiked } \\
\text { level }\end{array}$} & \multicolumn{3}{|c|}{ Glycopyrrolate } & \multicolumn{3}{|c|}{ Formoterol } \\
\hline & & $\begin{array}{c}\text { Amount } \\
\text { added } \\
(\mu \mathrm{g} / \mathrm{ml})\end{array}$ & $\begin{array}{l}\text { Amount } \\
\text { present } \\
(\mu \mathrm{g} / \mathrm{ml})\end{array}$ & $\begin{array}{l}\text { Average } \\
\text { \%Recovery* } \\
\text { + \%RSD }\end{array}$ & $\begin{array}{c}\text { Amount } \\
\text { added } \\
(\mu \mathrm{g} / \mathrm{ml})\end{array}$ & $\begin{array}{c}\text { Amount } \\
\text { present } \\
(\mu \mathrm{g} / \mathrm{ml})\end{array}$ & $\begin{array}{l}\text { Average } \\
\text { \%Recovery* } \\
\text { + \%RSD }\end{array}$ \\
\hline $1(n=6)$ & $50 \%$ & 2.25 & 2.23 & $99.14+0.45$ & 1.20 & 1.21 & $99.90+0.79$ \\
\hline $2(n=6)$ & $100 \%$ & 4.50 & 4.46 & $99.07+0.64$ & 2.40 & 2.40 & $99.86+0.88$ \\
\hline $3(n=6)$ & $150 \%$ & 6.75 & 6.75 & $99.99+0.75$ & 3.60 & 3.58 & $99.38+0.90$ \\
\hline
\end{tabular}

RSD-Relative standard deviation. ${ }^{*} \mathrm{n}=6$ (Average of 6 determinations)

\begin{tabular}{|c|c|c|c|c|c|c|}
\hline \multirow{2}{*}{ S.No } & \multicolumn{3}{|c|}{ Glycopyrrolate } & \multicolumn{3}{|c|}{ Formoterol } \\
\hline & Conc $(\mu \mathrm{g} / \mathrm{ml})$ & $\operatorname{Rt}(\min )$ & Area & Conc $(\mu \mathrm{g} / \mathrm{ml})$ & $\operatorname{Rt}(\min )$ & Area \\
\hline 1 & 9 & 2.281 & 121357 & 4.8 & 2.84 & 79815 \\
\hline 2 & 9 & 2.284 & 121377 & 4.8 & 2.846 & 79621 \\
\hline 3 & 9 & 2.286 & 122137 & 4.8 & 2.848 & 79104 \\
\hline 4 & 9 & 2.286 & 121585 & 4.8 & 2.848 & 79163 \\
\hline 5 & 9 & 2.288 & 122276 & 4.8 & 2.85 & 79872 \\
\hline 6 & 9 & 2.289 & 121589 & 4.8 & 2.852 & 79801 \\
\hline Mean & & & 121720 & & & 79563 \\
\hline SD & & & 392 & & & 343 \\
\hline$\%$ RSD & & & 0.32 & & & 0.43 \\
\hline
\end{tabular}

RSD-Relative standard deviation. Rt-Retention Time. 


\begin{tabular}{|c|c|c|c|c|c|c|}
\hline \multirow{2}{*}{ S.No } & \multicolumn{3}{|c|}{ Glycopyrrolate } & \multicolumn{3}{|c|}{ Formoterol } \\
\hline & Conc $(\mu \mathrm{g} / \mathrm{ml})$ & $\operatorname{Rt}(\min )$ & Area & Conc $(\mu \mathrm{g} / \mathrm{ml})$ & $\operatorname{Rt}(\min )$ & Area \\
\hline 1 & 9 & 2.283 & 123493 & 4.8 & 2.85 & 79864 \\
\hline 2 & 9 & 2.284 & 123142 & 4.8 & 2.851 & 79534 \\
\hline 3 & 9 & 2.285 & 123209 & 4.8 & 2.853 & 79347 \\
\hline 4 & 9 & 2.29 & 122813 & 4.8 & 2.853 & 79644 \\
\hline 5 & 9 & 2.29 & 120345 & 4.8 & 2.853 & 79737 \\
\hline 6 & 9 & 2.291 & 121332 & 4.8 & 2.853 & 79974 \\
\hline Mean & & & 122389 & & & 79683 \\
\hline SD & & & 1260 & & & 227 \\
\hline \%RSD & & & 1.03 & & & 0.28 \\
\hline
\end{tabular}

RSD-Relative standard deviation. Rt-Retention Time.

\begin{tabular}{|c|c|c|c|c|}
\hline \multirow{4}{*}{ S.No } & \multicolumn{4}{|c|}{ Inter-day Precison } \\
\hline & \multicolumn{2}{|c|}{ Day-1 } & \multicolumn{2}{|c|}{ Day-2 } \\
\hline & \multicolumn{2}{|c|}{ Peak area } & \multicolumn{2}{|c|}{ Peak area } \\
\hline & Glycopyrrolate $(9 \mu \mathrm{g} / \mathrm{ml})$ & Formoterol $(4.8 \mu \mathrm{g} / \mathrm{ml})$ & Glycopyrrolate $(9 \mu \mathrm{g} / \mathrm{ml})$ & Formoterol $(4.8 \mu \mathrm{g} / \mathrm{ml})$ \\
\hline 1 & 124148 & 76129 & 124224 & 76024 \\
\hline 2 & 124616 & 76322 & 124648 & 76125 \\
\hline 3 & 124723 & 76509 & 124337 & 75946 \\
\hline 4 & 124098 & 76237 & 124089 & 76246 \\
\hline 5 & 124042 & 75963 & 124145 & 75832 \\
\hline 6 & 124027 & 75982 & 124702 & 76366 \\
\hline Mean & 124276 & 76190 & 124358 & 76090 \\
\hline SD & 310 & 210 & 260 & 197 \\
\hline$\%$ RSD & 0.25 & 0.28 & 0.21 & 0.26 \\
\hline
\end{tabular}

RSD-Relative standard deviation.

\section{Table 3.2(B): Intermediate Precision Data (Instrument To Instrument Variability) of Glycopyrrolate and}

Formoterol.

\begin{tabular}{|c|c|c|c|c|}
\hline \multirow{2}{*}{ S.No } & \multicolumn{3}{|c|}{ Inter-Instrument Precison } \\
\cline { 2 - 5 } & \multicolumn{2}{|c|}{ Instrument-1 } & \multicolumn{2}{c|}{ Instrument-2 } \\
\cline { 2 - 5 } & \multicolumn{2}{|c|}{ Peak area } & \multicolumn{2}{c|}{ Peak area } \\
\cline { 2 - 5 } & $\begin{array}{c}\text { Glycopyrrolate } \mathbf{( 9 \mu g /} \\
\mathbf{m l})\end{array}$ & $\begin{array}{c}\text { Formoterol } \\
(\mathbf{4 . 8} \boldsymbol{\mu g} / \mathrm{ml})\end{array}$ & $\begin{array}{c}\text { Formoterol } \\
\mathbf{( 4 . 8} \boldsymbol{\mu g} / \mathrm{ml})\end{array}$ \\
\hline 1 & 124454 & 76957 & 124422 & 76428 \\
\hline 2 & 124125 & 76223 & 124854 & 76521 \\
\hline 3 & 124327 & 76905 & 124733 & 75649 \\
\hline 4 & 124980 & 76373 & 124982 & 76523 \\
\hline 5 & 124420 & 75658 & 124584 & 75238 \\
\hline 6 & 124284 & 75587 & 124631 & 76668 \\
\hline Mean & 124432 & 76284 & 286 & 76171 \\
\hline SD & 293 & 588 & 0.23 & 584 \\
\hline
\end{tabular}

RSD-Relative standard deviation. Rt-Retention Time. 


\section{Limit of detection and Limit of Quantification}

The values of the LOD and LOQ were computed from the calibration curve with the help of slope and standard deviation as per ICH guidance. The LOD and LOQ of Glycopyrrolate were observed to be $0.098 \mu \mathrm{g} / \mathrm{ml}$ and $0.298 \mu \mathrm{g} / \mathrm{ml}$ respectively. The LOD and LOQ of Formoterol were found to be $0.070 \mu \mathrm{g} / \mathrm{ml}$ and $0.213 \mu \mathrm{g} / \mathrm{ml}$ respectively. The outcomes were given in Table 4.

\section{Robustness}

Robustness was done by little considerable changes within the chromatographic conditions and retention time of Glycopyrrolate and Formoterol were noted. The factors chosen are rate of flow and variation within the composition of mobile phase. The outcomes were not affected by little variations in these parameters as appeared in Table 5(A) and 5(B).

\section{Assay}

The assay and purity were computed for brand BEVESPI AEROSPHERE (AstraZeneca) with label claim $9 \mathrm{mg}$ and $4.8 \mathrm{mg}$. The observed value was evaluated by comparing with the standard value without impedance from the excipients utilized in the tablet dosage form. The outcomes were given in Table 6 .

\section{Degradation studies}

\section{Acid Degradation Studies}

One $\mathrm{ml}$ of $2 \mathrm{~N}$ Hydrochloric acid was included to $1 \mathrm{ml}$ stock solution of Glycopyrrolate and Formoterol and refluxed for $30 \mathrm{~min}$ at 600 . The resultant solution was diluted to get $9 \mu \mathrm{g} / \mathrm{ml}$ and $4.8 \mu \mathrm{g} / \mathrm{ml}$ solution and $10 \mu \mathrm{l}$ solutions were injected into the system and the chromatograms were recorded to evaluate the stability of sample.

Table 4: LOD and LOQ of Glycopyrrolate and Formoterol.

\begin{tabular}{|c|c|c|}
\hline & Glycopyrrolate & Formoterol \\
\hline LOD & 0.098 & 0.070 \\
\hline LOQ & 0.298 & 0.213 \\
\hline
\end{tabular}

\begin{tabular}{|c|c|c|c|c|c|c|c|}
\hline \multicolumn{9}{|c|}{ Table 5(A): Robustness Data Relating to Change in Flow Rate (1.0 ml/min). } \\
\hline \multirow{2}{*}{ S.No } & \multicolumn{3}{|c|}{ Glycopyrrolate } & \multicolumn{4}{c|}{ Formoterol } \\
\cline { 2 - 8 } & Flow rate (ml/min) & $\begin{array}{c}\text { Average } \\
\text { Peak Area* }\end{array}$ & SD & $\% R S D$ & $\begin{array}{c}\text { Average } \\
\text { Peak Area* }\end{array}$ & SD & \%RSD \\
\hline 1 & $0.9 \mathrm{ml} / \mathrm{min}$ & 124674 & 347 & 0.28 & 76497 & 359 & 0.47 \\
\hline 2 & $1.0 \mathrm{ml} / \mathrm{min}$ & 124447 & 200 & 0.16 & 76374 & 380 & 0.50 \\
\hline 3 & $1.1 \mathrm{ml} / \mathrm{min}$ & 124492 & 240 & 0.19 & 76150 & 853 & 1.12 \\
\hline
\end{tabular}

RSD-Relative standard deviation. * $\mathrm{n}=3$ (Average of 3 determinations)

\begin{tabular}{|c|c|c|c|c|c|c|c|}
\hline \multicolumn{9}{|c|}{ Table 5(B): Robustness Data Relating to Change in Mobile Phase Composition. } \\
\hline \multirow{2}{*}{ S.No } & \multicolumn{3}{|c|}{ Glycopyrrolate } & \multicolumn{3}{c|}{ Formoterol } \\
\cline { 2 - 8 } & Mobile phase variation (\%) & $\begin{array}{c}\text { Average } \\
\text { peak } \\
\text { area* }\end{array}$ & SD & \%RSD & $\begin{array}{c}\text { Average } \\
\text { peak } \\
\text { area* }\end{array}$ & SD & $\%$ RSD \\
\hline 1 & M.P-1-(BUFFER:ACN::41:59) & 124777 & 298 & 0.24 & 75673 & 592 & 0.78 \\
\hline 2 & M.P-2-(BUFFER:ACN::40:60) & 124822 & 718 & 0.58 & 76397 & 185 & 0.24 \\
\hline 3 & M.P-3-(BUFFER:ACN::39:61) & 124659 & 458 & 0.37 & 76199 & 749 & 0.98 \\
\hline
\end{tabular}

$R S D$-Relative standard deviation. $* \mathrm{n}=3$ (Average of 3 determinations)

\begin{tabular}{|c|c|c|c|c|c|c|}
\hline \multirow[b]{2}{*}{ S.No } & \multirow[b]{2}{*}{ Sample } & \multirow[b]{2}{*}{ Label } & \multicolumn{2}{|c|}{ Glycopyrrolate } & \multicolumn{2}{|c|}{ Formoterol } \\
\hline & & & Amount found & $\begin{array}{l}\text { \%Purity } \\
\text { + RSD* }\end{array}$ & Amount found & $\begin{array}{l}\text { \%Purity } \\
\text { + RSD* }\end{array}$ \\
\hline 1 & $\begin{array}{c}\text { Brand-1 } \\
\text { BEVESPI AEROSPHERE }\end{array}$ & $9 \mathrm{mg} / 4.8 \mathrm{mg}$ & 8.99 & $99.46+0.61$ & 4.46 & $98.74+0.36$ \\
\hline
\end{tabular}

RSD-Relative standard deviation. ${ }^{*} \mathrm{n}=3$ (Average of 3 determinations) 


\begin{tabular}{|c|c|c|c|c|}
\hline & \multicolumn{2}{|c|}{ Glycopyrrolate } & \multicolumn{2}{|c|}{ Formoterol } \\
\hline & \%Assay & Degraded & \%Assay & Degraded \\
\hline Acid & 94.50 & -5.50 & 95.56 & -4.44 \\
\hline Alkaline & 96.89 & -3.11 & 97.65 & -2.35 \\
\hline Peroxide & 97.97 & -2.03 & 98.52 & -1.48 \\
\hline Thermal & 98.63 & -1.37 & 99.39 & -0.61 \\
\hline UV & 98.52 & -1.48 & 99.70 & -0.30 \\
\hline Water & 98.86 & -1.14 & 99.28 & -0.72 \\
\hline
\end{tabular}

\section{Alkali Degradation Studies}

To $1 \mathrm{ml}$ stock solution of Glycopyrrolate and Formoterol, $1 \mathrm{ml}$ of $2 \mathrm{~N}$ sodium hydroxide was included and refluxed for $30 \mathrm{~min}$ at $60^{\circ}$. The resultant solution was diluted to obtain $9 \mu \mathrm{g} / \mathrm{ml}$ and $4.8 \mu \mathrm{g} / \mathrm{ml}$ solution and $10 \mu \mathrm{l}$ were injected into the system and the chromatograms were recorded to evaluate the stability of sample.

\section{Oxidation}

To $1 \mathrm{ml}$ of stock solution of Glycopyrrolate and formoterol $1 \mathrm{ml}$ of $20 \%$ hydrogen peroxide $\left(\mathrm{H}_{2} \mathrm{O}_{2}\right)$ was included separately. The solutions were maintained at $60^{\circ}$ for about $30 \mathrm{~min}$. The resultant solution was diluted to acquire $9 \mu \mathrm{g} / \mathrm{ml}$ and $4.8 \mu \mathrm{g} / \mathrm{ml}$ and $10 \mu \mathrm{l}$ were injected into the system and afterwards chromatograms were recorded to evaluate the stability.

\section{Dry Heat Degradation Studies}

The standard drug solution was kept in oven in for $6 \mathrm{~h}$ at $105^{\circ}$ to check dry heat degradation. For HPLC study, the resultant solution was diluted to $9 \mu \mathrm{g} / \mathrm{ml}$ and $4.8 \mu \mathrm{g} / \mathrm{ml}$ solution and $10 \mu \mathrm{l}$ were injected into the system and the chromatograms were recorded to evaluate the sample stability.

\section{Photo Stability studies}

The drug's photochemical stability was also evaluated by exposing the $9 \mu \mathrm{g} / \mathrm{ml}$ and $4.8 \mu \mathrm{g} / \mathrm{ml}$ solution to UV Light by keeping the beaker in UV Chamber for 7 days in a photo stability chamber. For HPLC study, the resultant solution was diluted to obtain $9 \mu \mathrm{g} / \mathrm{ml}$ and $4.8 \mu \mathrm{g} / \mathrm{ml}$ solutions and $10 \mu \mathrm{l}$ were injected into the system and the chromatograms were recorded to evaluate the sample stability.

\section{Neutral Degradation Studies}

Stress testing was performed under neutral conditions at a temperature of $60^{\circ}$ by refluxing the drug in water for 6h. For HPLC study, the resultant solution was diluted to $9 \mu \mathrm{g} / \mathrm{ml}$ and $4.8 \mu \mathrm{g} / \mathrm{ml}$ solution and $10 \mu \mathrm{l}$ were injected into the system and the chromatograms were recorded to assess the stability of the sample.
The results of all the degradation studies were presented in Table 7.

\section{RESULTS}

A reverse-phase column methodology was proposed as an appropriate strategy for the concurrent estimation of Glycopyrrolate and Formoterol dosage form. The optimization in chromatographic conditions was performed by changing the composition in mobile phase. The optimization of mobile phase was performed by testing at different ratios. But, buffer and acetonitrile in the ratio $40: 60 \mathrm{v} / \mathrm{v}$ was utilized as mobile phase, which demonstrated good resolution of Glycopyrrolate and Formoterol peak. The wavelength chosen for detection was $241 \mathrm{~nm}$, because the drug showed best peak area. The retention times of Glycopyrrolate and Formoterol were $2.290 \mathrm{~min}$ and $2.853 \mathrm{~min}$ respectively without intereference from any impurities in the assay. The retention times of Glycopyrrolate and Formoterol are $2.290 \mathrm{~min}$ and $2.853 \mathrm{~min}$, respectively. The linearity for Glycopyrrolate and Formoterol are $2.25-13.5 \mu \mathrm{g} / \mathrm{ml}$ and $1.2-7.2 \mu \mathrm{g} / \mathrm{ml}$ respectively. The recoveries of Glycopyrrolate and Formoterol were observed to be 99.17 to $100.66 \%$ and 98.36 to $100.79 \%$ respectively.

\section{DISCUSSION}

The objective is to develop and validate a fundamental, specific, novel and exact RP-HPLC (Reverse phase-High performance Liquid chromatography) methodology for the synchronous determination of Glycopyrrolate and Formoterol in pharmaceutical dosage form. The same has been developed and this method is simple, economical, rapid, precise accurate and sensitive, as per the information on the drug recovery data and statistical analysis of data. This method can be easily adopted for regular quality control analysis. The outcomes of this analysis affirmed that the method is appropriate for determination of drug in various pharmaceutical formulations without any interference of excipients. Thus the proposed strategy 
can be applied in simultaneous estimation of Glycopyrrolate and Formoterol in marketed formulations.

\section{CONCLUSION}

This method is fast, precise and sensitive. It makes utilization of less amounts of solvents and changes to the set of conditions can be done within short period of time. This strategy can be suitably applied for the normal examination of Glycopyrrolate and Formoterol in various dosage forms. It doesn't experience the interference because of availability of regular excipients in different dosage forms and can be helpfully applied for quality control examination.

\section{ACKNOWLEDGEMNT}

The authors are thankful to Astra Zeneca for supplying Glycopyrrolate and Formoterol.

\section{CONFLICT OF INTEREST}

Author declares no conflict of interest.

\section{ABBREVIATIONS}

Rt: Retention Time; RSD: Relative Standard Deviation; Concn: Concentration; NMT: Not more than; ACN: Acetonitrile.

\section{REFERENCES}

1. Bevespi Aerosphere ${ }^{\mathrm{TM}}$ (glycopyrrolate and formoterol fumarate) Prescribing information, Astrazeneca 2016.

2. https://www.drugs.com/pro/glycopyrrolate-injection.html

3. Mishra S, Arora V. Analytical method validation of HPLC method for assay of anticholinergic drug in parenteral formulation. International Journal for Pharmaceutical Research Scholars. 2016;5(4):101-4.

4. Shah PD, Koradia S. Simultaneous determination of beclomethasone Dipropionate and formoterol fumarate in rotacap Dosage form using two different Spectrophotometric methods. World Journal of Pharmacy and Pharmaceutical Sciences. 2014;3(5):611-23.
5. Pabba KG, Akula G. RP-HPLC Method development and validation for estimation of glycopyrrolate in bulk and tablet dosage forms. Asian Journal of Pharmaceutical and Clinical Research. 2011;4(4):37-40.

6. Stormea ML, t'Kindt RS, Goeteyn W, Reyntjens K, Van Bocxlaer JF. Quantitative determination of glycopyrrolate in human plasma by liquid chromatography-electrospray ionization mass spectrometry: The use of a volatile ion-pairing agent during both liquid-liquid extraction and liquid chromatography. J. Chromatogr. B. 2008;876(1):24-30.

7. Rumpler MJ, Sams RA, Colahan P. Validation of liquid chromatographyTandem mass spectrometry method for quantification of Glycopyrrolate in horse plasma. J Anal Toxicol. 2011;35(9):656-64.

8. Campestrini J, Lecaillon JB, Godbillon J. Automated and sensitive method for the determination of formoterol in human plasma by high-performance liquid chromatography and electrochemical detection. J. Chromatogr. B. 1997;704(1-2):221-9.

9. Srinivasu K, Rao JV, Raju NA, Mukkanti K. Simultaneous RP-HPLC Method for the estimation of Formoterol Fumarate and Tiotropium Bromide in pharmaceutical dosage forms. Asian J. Chem. 2010;22(5):3943-8.

10. Nanasaheb RK, Ashok PP, Javed AM, Govind ND. Development and validation of stability-indicating RP-HPLC method for simultaneous estimation of Formoterol Fumarate and Budesonide in metered dose inhaler formulation. World Journal of Pharmaceutical Research. 2014;3(6):1386-99.

11. Zanwar AS, Sen DB, Ruikar DB, Seth AK. Spectroscopic methods for the simultaneous estimation of Mometasone Furoate and Formoterol Fumarate in Rotacaps. Indo American Journal of Pharmaceutical Research. 2014;4(12):5928-33.

12. Merey HA, El-Mosallamy SS, Hassan NY, El-Zeany BA. Validated chromatographic methods for the simultaneous determination of Mometasone furoate and Formoterol fumarate dihydrate in a combined dosage form. Bulletin of Faculty of Pharmacy, Cairo University. 2016;54(1):99-106.

13. Srinivasarao K, Gorule V, Venkata RCh, Venkata KA. Validated Method Development for Estimation of Formoterol Fumarate and Mometasone Furoate in Metered Dose Inhalation Form by High Performance Liquid Chromatography. J Anal Bioanal Techniques. 2012;3(7):1-4.

14. Prasad AV. Simultaneous spectroscopic determination of formoterol fumarate and budesonide in their combined dosage form. Indian J. Chem. Technol. 2006;13:81-3.

15. Pai N, Patil SS. Development and validation of RP-HPLC method for estimation of formoterol fumarate and budesonide in pressurised meter dose inhaler form. Der Pharmacia Sinica. 2013;4(4):15-25.

16. Malik K, Kumar D, Tomar V, Kaskhedikar S, Soni L. Simultaneous Quantitative Determination of Formoterol Fumarate and Fluticasone Propionate by Validated Reversed-Phase HPLC Method in Metered dose inhaler. Der Pharmacia Sinica. 2011;2(6):77-84.

17. $\mathrm{ICH}$ harmonized tripartite guideline; validation of Analytical procedures: Text and Methodology Q2 (R1). International Conference on Harmonisation of Technical Requirements for Registration of Pharmaceuticals for Human Use. 2005. 11-12.

\section{SUMMARY}

- Glycopyrrolate, as other anticholinergic (antimuscarinic) drugs, impedes the action of acetylcholine on structures innervated by postganglionic cholinergic nerves and on smooth muscles that respond to acetylcholine yet require cholinergic innervation

- Formoterol acts as a bronchodilator. It extends the airways of the lungs, so that it helps to inhale all the more effortlessly. It may even be utilized to forestall respiratory issues caused by exercise.

- There are various methods for determination for single Glycopyrrolate and Formoterol, and no reported method was available for the simultaneous determination of Glycopyrrrolate and Formoterol.

- The present method was to build up a straightforward, minimal effort RP-HPLC technique for concurrent estimation of Glycopyrrolate and Formoterol and can be applied successfully for bulk and also in other dosage forms. 


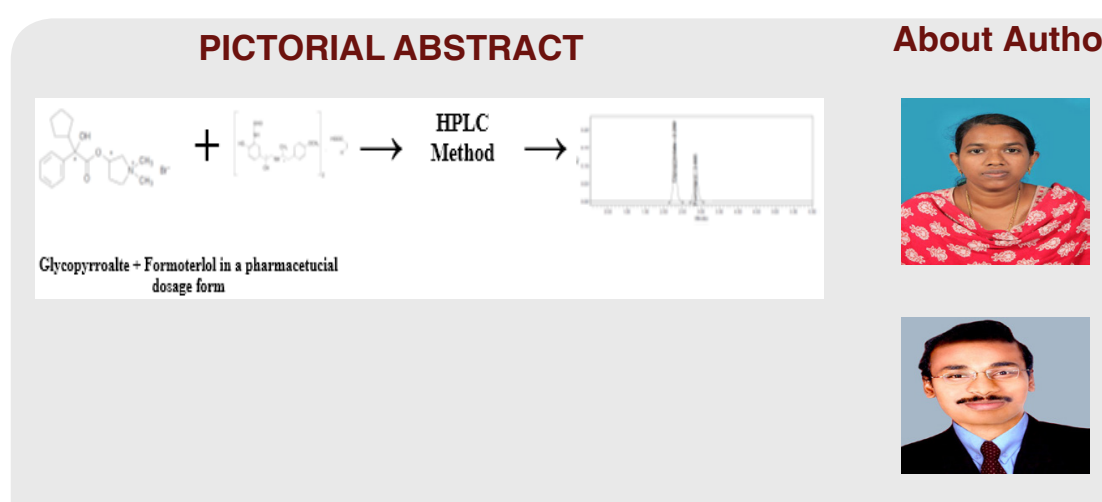

\section{About Authors}

Dr. Suseem Sundaram Rengitham: Academic researcher, with research interests in new molecule synthesis, stability studies of drug substances and analytical method development.

Kishor kumar Erukulla: Research Scientist, with research interests in Clinical Research, Drug development, Bio-statistics, and analytical method development.

Cite this article: Erukulla KK, Suseem SR. Synchronous Estimation of Glycopyrrolate and Formoterol in Bulk and Pharmaceutical Dosage Form by RP-HPLC Method. Indian J of Pharmaceutical Education and Research. 2018;52(4S):S47-S55. 